European journal of American studies

\title{
AIDS, Caregiving and Kinship: The Queer "Family" in Bill Sherwood's Parting Glances
}

Nikola Stepić

\section{(2) OpenEdition \\ Journals}

Electronic version

URL: https://journals.openedition.org/ejas/11761

DOI: $10.4000 /$ ejas. 11761

ISSN: 1991-9336

Publisher

European Association for American Studies

Electronic reference

Nikola Stepić, "AIDS, Caregiving and Kinship: The Queer "Family" in Bill Sherwood's Parting Glances", European journal of American studies [Online], 11-3 | 2017, document 9, Online since 13 March 2017, connection on 08 July 2021. URL: http://journals.openedition.org/ejas/11761 ; DOI: https://doi.org/ 10.4000/ejas. 11761

This text was automatically generated on 8 July 2021.

Creative Commons License 


\title{
AIDS, Caregiving and Kinship: The Queer "Family" in Bill Sherwood's Parting Glances
}

\author{
Nikola Stepić
}

\section{Introduction: From Family to "Family"}

Contemporary dramatizations of queer lives in popular media work hard to frame the image of queerness in American popular culture as something palatable, identifiable and, ultimately, normal. These visual representations, framed within the traditionally family-friendly and family-oriented genres of soap opera and situation comedy (Desperate Housewives, Modern Family, The New Normal and many others), reveal the centrality of gay marriage within the queer political discourse. In his seminal book, The Trouble with Normal, social theorist Michael Warner investigates the assumed centrality of gay marriage within the larger queer argument from a political and ideological standpoint, stating that "[marriage] became the dominant issue in lesbian and gay politics of the 1990s, but not before" (87). Similarly, Judith Stacey writes that the biological family was perceived as exactly the locus of injustice and exclusion in the context of the gay liberation movements in the 1960s and 1970s (144).

The strides towards obtaining the privileges that marriage provides suggest emulation and assimilation into heteronormativity, a shift in perception of queer living that is easily observable in today's media-prescribed representations of acceptable queerness that work to legitimize the gay and lesbian experience through marital visibility. Furthermore, this kind of legitimization also calls into question the ethics of a host of benefits-legal, social, and otherwise-remaining exclusive to marriage. Although a discussion on the trappings of queer visibility through marriage is well beyond the scope of this paper, it should nonetheless be acknowledged as a crucial part of its framework. The idea of the normative family as "an arbiter of benefits" (19), and particularly the contemporary reliance on this structure, which "[allows] the state to 
mandate that only some relationships and some forms of social networks count" (20), to quote Yasmin Nair, is central to the discussion on queer kinship at a time where access to the privileges of marriage remained unavailable.

In his study titled Family, Drama, and American Dreams, Tom Scanlan argues that "the family situation is the crucial subject of American drama," the examination of which is in fact a study of "a habit of mind, a pattern of values and ideology" (3). While Scanlan's 1978 book does not address queer life, the argument that the family as a social unit and an ideology is central to American identity, as communicated through its dramatic output, is a crucial entry point into the queer cinematic canon, especially in light of today's insistence of framing gay subjectivity within the familial framework. ${ }^{1}$ In fact, Scanlan identifies the main problem of twentieth-century drama, "[from] O'Neill on," as "family life strained by the conflicting tensions of security and freedom, mutuality and selfhood" (49). The pertinent question at hand is how this familial tension that is at the center of American cultural output has been reproduced and (re)negotiated in the queer cultural canon, as queer subjects could not simply be exempt from the ostensible centrality of the familial in national culture due only to their historical inability to marry and in turn form "legitimate" families of their own.

Psychologist R. D. Laing wrote extensively and influentially on family relationships, and in his 1971 article, "The Family and the "Family," made a key distinction between family of origin, or a family's apparent structure and elements, and the internalized family (alternatively distinguished by quotation marks), or an acquired understanding of a family's elements and their relationships and operations (4). Such a "family" operates as a fantasy structure constructed on a sense of peer similarity between its participants, rooted in a common we and a common them. Laing explains this commonality as part of the process of internalization-the mapping of 'outer' onto 'inner"' (7), or differently put, the perception of a set of relations and objects as "patterns of relationship" (8). The centrality of familial life that both Laing and Scanlan note is then perpetuated by the process of transference, "of a group of relations constituting a set... from one modality of experience to others" (7), through which a "family," this psychologically internalized version of one's family, is projected onto another mode of sociality.

To look at the evolution of queer familial life, and specifically the queer cinematic canon, vis-à-vis Laing, means to look at a long process of transference, marked on the one hand by queer struggle and the inability to partake in familial life, and on the other hand the cultural output that has negotiated queers' "outsider" status through codification and reevaluation of the family itself. What came before the gay family as the political bottom line has certainly been affected by the centrality of the family as a social structure and a factor of identity formation. Thus, to uncover the familial within the queer with a consciousness of today's assimilation of queerness into the familial is to hopefully uncover a different way of relating-an intimacy and a kinship that challenges and subverts as much as it emulates and compromises. To this end, this paper looks at the 1986 film Parting Glances (Bill Sherwood) as a case study which not only illustrates an intersection of the queer and the familial, but also its potential for empowering the constituents of these urban, chosen families, and particularly so in the affecting time of the AIDS epidemic. Moreover, the paper seeks to demonstrate that narratives of queer kinship are no mere emulation of a social landscape conditioned to think in terms of the familial and domestic, nor are they 
works that seek to flatter heteronormativity; rather, they work to disrupt and critically engage with the family's traditionally ascribed organization and authority.

\section{Caregivers: Buddies and Lovers}

Thomas Waugh argues that melodrama has traditionally been the cinematic genre of choice for women and gay men alike, due to both of these groups' position "outside patriarchal power, in ambiguous and contradictory relationship to it" (123). It is not surprising, then, that, other than in activist filmmaking of the time, representations of AIDS found their natural form in the genre, as they combine "tears," "political lucidity" and "other bodily secretions" (Waugh 124). These films also, however, form an important point of entry into the discussion of queer kinship. On the one hand, the melodramatic conventions are already rooted in exposing "the way that sexual difference under patriarchy is fraught, explosive and erupts dramatically into violence within its own private stamping ground, the family" (Mulvey, qtd. in Hayward 230), as Waugh himself also implies. On the other hand, the domesticity that pervades melodrama, hand in hand with the AIDS crisis itself, ushers even more familial tropes into queer narratives and, quite literally, queer spaces: tropes such as caregiving, mourning and funerals, to name a few, work alongside those of family reunion, confession, and childhood trauma.

In her book, AIDS Literature and Gay Identity, Monica B. Pearl recognizes the importance of burials and mourning, and posits that "the repetition of burials for the gay community during the time of AIDS had the effect of cementing the community as a common community" (8). She goes on to explain, however, that this was not the first time the circumstance of death acted as glue in the formation of queer communities. She writes that parental fear of having gay children is one of the main phenomena that linked queerness and death in the first place-biological death, but also the "death of innocence, death of heterosexual identity, death of parental/adult authority, death of the natural order" (8). In this light, one cannot speak of death in the gay community, especially in time of AIDS, without remaining conscious of the difficult relationship between family, homosexuality and mortality. Consider, for example, Norman René's Longtime Companion (1989), a film where the AIDS crisis is imagined specifically as this "repetition of burials." Its final scene, where a couple of friends fantasize that their loved ones will join them on the beach on Fire Island for one last party from beyond the grave, underscores the relationship between death and the gay community. Furthermore, one need not look further than the first television movie made on the subject of AIDS, John Erman's An Early Frost (1985), for a narrative that juxtaposes the "coming out" story to that of a deadly affliction, as it centers on a young man who returns to his family in order to reveal that he is gay and diagnosed with AIDS. In the face of sickness and death, especially when AIDS literalized that progression so compactly as it did in the 1980s and 1990s, family and its tropes are bound to not only resurface, but take center stage in the form of caregivers, lovers, friends and even antagonists.

The trope of caregiving is at the center of AIDS community formation, as well as its filmic representation. Following the paradigm set by Michel Foucault and furthered by Tom Roach in his book on queer friendship titled Friendship as a Way of Life, this relationality stems from a fertile space of human involvement located somewhere 
between two models of sanctioned gay behavior, the hook-up and the emulation of heterosexual conventions in a "lovers' fusion of identities" (46). Indeed, caring for the PWA's body and spirit creates a diverse relational space filled with either family or "family"-a host of lovers, friends or "buddies." The newly created mode of relationality and caregiving dubbed "the buddy friendship" is discussed both by Roach and Waugh in terms that widely draw caregiving as labor particular to the formation of "families." For example, in his discussion of Buddies (Arthur J. Bressan, Jr.), Waugh underscores in the volunteer's relationship with the character dying of AIDS a crucial sexual dimension. Providing sexual release to a person with AIDS (PWA in the remainder of the text) through masturbation, Waugh argues, "becomes an affirmation of [the PWA's] identity, a bond between him and the world, an assurance that he will not die alone" (125). Roach, on the other hand, describes the buddy friendship as a "framework encouraging certain intimacies" and an "experiment in difference" (112), claiming that its goal "is not to eliminate social / economic / health dissymmetries from the relationship but to maintain them precisely as a productive tension" (112-113). Not only does this reading of buddy friendships imply parrhesia, an alternative to confession whose goal is "to aid the listener and speaker alike in developing an autonomous, independent, full and satisfying relationship to himself" (Roach 24, emphasis added), but also with it being this experiment in difference (of health statuses, but also of socioeconomic backgrounds, age, gender or sexual identities), it relates to another staple of friendship as theorized by Foucault, that of "shared estrangement." In recognizing AIDS as a moment, both cultural and personal, in which life and death are visibly hanging in the balance, Roach writes of "estrangement from others and the world" that necessarily happens in the psyche. He sees this estrangement as inherently productive, however, as he reads Foucault's relationship with mortality as "[contemplating] death's immanence to life and arguably [cultivating] a relationship with death adversative to biopolitical dictates" (39). Combining this culturally shared estrangement that draws attention to and works against biopolitical (but also essentialist and patriarchal) control with the idea of the buddy system as a version of caregiving that mixes medical, intellectual and sexual care, brings us back to the idea of "family" as a fluid and potentially subversive mode of relating implicit in the relationship between a PWA and a healthy "buddy."

The structure of Parting Glances, the 1986 feature film directed by Bill Sherwood and a key entry into the AIDS film canon due to its uncompromising portrayal of the PWA, implies that, at a basic level, the film serves as a panorama of queer urban life, rooted in the melancholy and transience typical of the AIDS crisis. Indeed, the film takes place over a 24-hour period and is bookended with shots of the Soldiers' and Sailors' Monument in Manhattan's Upper West Side. The locales and situations the characters find themselves in follow, in short succession, their private spaces, with the characters shown in their respective apartments, then at a dinner party, and then, finally at a house party; public spaces, at the Soldiers' and Sailors' Monument, for example, or at a Manhattan nightclub; and finally Fire Island, the popular seaside resort for gay men and a satellite of sorts of New York's urban gay living. However, along with its possible status as a queer city film, the centrality of the PWA character, Nick (played with much gusto by Steve Buscemi), transforms the narrative into one about the specific negotiations of "family," as the characters' fluid relationships make up the film's main conflict, while the omnipresence of AIDS reorganizes these relationships into a delicate web of obligation, responsibility and caregiving. 
The plot of the film concerns the main character, Michael (played by Richard Ganoung), and his negotiation of his parallel relationships with his partner Robert (John Bolger) and his best friend Nick, who is living with AIDS. There is palpable tension between Michael and Robert from the outset, as Robert is not only to go away to Brazil on business, but is also avoiding saying goodbye to Nick before he leaves. This awkward emotional ménage à trois is best described by the film's two early scenes, the first set in Michael and Robert's apartment where we see them having sex, packing Robert's bags for the trip, and Michael working. Their domesticity is quickly replaced by that of Michael and Nick, as the former pays a visit to his friend's apartment where he lives in relative solitude, spending his days listening to music and watching one of his many television sets. Michael navigates Nick's apartment with comfort and familiarity: he has his own set of keys, he makes Nick his protein shake and goes through his medicine cabinet. They spend their time talking, arm wrestling and playing cards. As Waugh puts it, "Comfort is implicitly shared back and forth through caresses, touching, looks and smiles" (129). The intimacy, and even physical closeness Michael has with Nick, is comparable to the closeness he has with his partner, as the film draws a parallel between romantic and friendly love. Waugh describes the time they spend together as "[the] strengthening of his relationship with Nick, his AIDS-stricken buddy, a character for whom he has always had an unacknowledged and unrequited love deeper even than his sexual love for the Gentlemen's Quarterly-style heel he lives withshades of Scarlett O'Hara's for Ashley Wilkes" (127). The love that Michael has for his buddy is reminiscent of friendship as theorized by Foucault and Roach as simultaneously private (rooted in conjugality) and communal (amicable, a product and a part of a community) (Roach 4), while the implied domesticity, intimacy and caregiving expand this understanding of friendship to include a sense of kinship and filiation inseparable from responsibility.

As is the case in other AIDS narratives set in, or emerging out of the 1980s, there is a pronounced tension regarding the PWA and the people in his life who carry the responsibility of caregiving. For example, the struggles of the character Ned in Larry Kramer's The Normal Heart, as he seeks to mobilize the gay community in the early years of AIDS and to spread awareness about the disease, are rooted in his own domestic situation, the cultural burden of AIDS condensed in his and his partner's own plagued relationship. Similarly, Jonathan Demme's 1993 film Philadelphia roots the public discourse surrounding AIDS in the domestic relationship between the PWA character Andrew (Tom Hanks) and his lover Miguel (Antonio Banderas), who expresses frustration when Andrew is considering skipping a treatment, mirroring an explosive scene of confrontation in The Normal Heart when Ned's ailing lover loses morale and refuses to eat healthily. Similar tension emitting from the responsibility of caregiving becomes one of the key conflicts in Tony Kushner's 1993 play Angels in America, as well as in the 2003 mini-series adaptation directed by Mike Nichols. The central character of Prior, a gay men in 1985, is abandoned by his longtime partner Louis after being diagnosed with AIDS, and their final reunion serves as one in a series of cathartic resolutions the narrative offers. It is interesting to note, however, that in both Philadelphia and The Normal Heart, even though both texts are undoubtedly concerned with community building and activist efforts as a response to the way AIDS was handled in judicial and political circles, the obligation to take care of a PWA is heavily staged within the domestic, almost conjugal relationship between the PWA and his partner. 
In contrast, both Angels in America and Parting Glances introduce a number of characters in between and around the PWA and his buddy. Parting Glances specifically features a host of people who, in one way or another, react to and are connected to Nick, typically through his buddy Michael. Just like in Angels in America, where the unlikely ties and connections made between people all somehow have Prior at their center, Parting Glances insists on extended networks of caregiving and support. These networks include Michael's straight girl friend, his and Robert's married, sexually ambiguous friends, and even members of their circle who have given up on Nick altogether, and who Michael continually badgers to reach out to their sick friend. In Sherwood's film, conjugality is imagined as an impediment to community formation, and more fluid and complex relationships that combine the private and the communal are valued above other modes of relating.

It is important to note that, while mentioned, there is no biological family to be seen in Parting Glances. That Michael at one point even verbalizes that he and his friends will have to be the ones to inform Nick's father of his condition after Nick passes not only reads as a very particular and paradigmatic responsibility in the context of the AIDS pandemic, but is also evocative of Monica B. Pearl's observation on queer filiation: "Romantic partnerships and biological families are understood to be the sources of disappointment not fidelity. In fact, families-biological families-have often been depicted as a constant source of terrible disappointment" (148). In this light, it is important to understand caregiving in Parting Glances, but also in other AIDS narratives, as a facet of the "family" that finds its shape in different relational categories. For example, Nick's relationship with Michael is best described as friendly, in spite (or, according to Foucault, precisely because) of their sexual tension. In turn, Michael counts on both his married friends and his own lover to provide him with strength and support. The latter relationship is one that particularly drives the characters' development in the latter half of the film, as Robert finally realizes that, for all of Michael's caregiving of Nick, Michael himself needs to be taken care of. As a result, the "family" registers as a diverse and complicated set of relationships among a variety of members.

The "family" as a fantasy structure, as R.D. Laing dubs it, is presented in Parting Glances as both indispensable and unfixed. The film's shifting focus as it surveys the Manhattan queer scene is reminiscent of Laing's hypothesis that 'the 'family' undergoes modulations and other transformations in the process of internalization and in its subsequent history as fantasy" (17). In other words, the "family" must remain flexible, depending on whoever its constituents may be at a given moment and on the kind of relationship they may forge. However, in spite of the "family's" inherent ambiguity, it ultimately results in a normalized idea of a milieu and its dynamics, which Parting Glances, like any other queer cultural text, can be seen as representing and reproducing. The atmosphere, aesthetics and the vocabulary of the film package this variety of relations as a particular "family" at a particular moment in time, in turn reproducing that "family's" conventions as a promise of virtual community. Pearl reads the queer literary output in a similar way when she theorizes that an "imagined gay community" that individuals long for, "is established at the level of representation through a culture of the printed word that is structured through reading and the imagined social space it produces" (7). Similarly, the emotional and visual spaces of Parting Glances (Michael and Nick's house, Fire Island, Manhattan, etc.) are reproduced 
as places and social configurations where "family" can take place and caregiving is scaffolded among the milieu's variety of members.

\section{A Felt Absence}

Parting Glances features a diverse cast of secondary characters (and members of Nick's extended "family") that are both male and female, gay and straight, and living a variety of lifestyles. This strategy is explained by Pilipp and Shull in the context of TV movies as one where "in order to appeal to rather than appall the populace," these films "redirect primary emphasis away from the anxieties, self-reproaches, and fears of the HIV-infected (or the world of homosexuals) and toward the reactions of those around him" (20). In spite of the obvious discriminatory implications in this shift of emphasis, it is remarkable how succinctly this argument suggests why AIDS films (made for television, or otherwise) are effectively about "family" inasmuch as they are about PWAs. Moreover, this line of reasoning echoes Roach's idea of AIDS activism and caregiving containing "seeds of a post-identitarian politics." Developing his idea of the buddy system as a parrhesiastic, creative dynamic, he posits that "in revealing the instability of national, cultural, and ethnic identities rooted in diversity, AIDS gives rise to a multitude of its own making" (107). Pearl also sees AIDS as a force that gives a sense of universality to gay existence where before it was so marginal and othered. She dubs AIDS "a universal signifier that applies equally to the lives of those who can be considered to dwell in the heterosexual mainstream and to the lives of gay men," and in that context, she sees the universal quest for romantic love to have been replaced by a quest for "an unconventional but still satisfying sense of family" (39). Even when Nick is absent from a scene in Parting Glances, his absence is felt. Not only does this make him and his condition omnipresent in the film, but it also unites this diverse set of characters, with Nick and his buddy Michael acting as common denominators.

Under the specter of AIDS, Sherwood's New York City becomes a place where people's relationships, friendships and even marriages, are in a constant state of flux. This fluidity of relationships is reflected in Nick's imminent mortality, acutely felt by his friends. Michael and Robert's separation carries a sense of dire finitude, because with Robert gone, Michael loses a support system he needs in dealing with his best friend's imminent passing. Their married friends Beth and Cecil, on the other hand, find comfort in each other even though Cecil prefers men, and that their marriage has an expiration date remains unchallenged-moreover, its eventual disintegration is portrayed as an inevitability that ushers in other potential relationships for both characters. Sherwood even introduces a leitmotif of Michael's Polish neighbors, a single mother and her young daughter who calls Michael "daddy" and who, when he points out that he is in fact not her father, replies with a whispered, "That's okay" (Parting Glances). In a city where people have a tendency to leave their loved ones, either by dying or by moving away, Sherwood insists on the ties that bind them while they are still together, no matter how short that time may turn out to be. The transient nature of urban relationships corresponds to Kylo-Patrick R. Hart's idea of the city as AIDS dystopia. Drawing from scholar Antony Easthope, Hart writes in his book, The AIDS Movie: Representing a Pandemic in Film and Television, that,

The city is presented as a site of transcendental (rather than social) alienation in which human life is experienced, ultimately, as being somewhat unfulfilling because something essential (even if not readily identifiable) is felt to be missing.... 
As such, the city is represented to be the place of AIDS infection, where death and

dying make up a depressingly regular component of everyday life. $(72,73)$

In light of Hart's view of the city as AIDS dystopia, it seems particularly meaningful that Sherwood universalizes the finitude Nick and his friends are facing by offsetting it with a whole host of relationships that are, in one way or another, dying. Furthermore, he imbues Roach's “multitude of its own making" with a sense of responsibility and caregiving. As is the case in so many other AIDS narratives, from the interplay of Mormonism, AIDS and other "national themes" in Angels in America, to the racially, socially and sexually diverse cast of Jonathan Larson's 1996 musical Rent, this multitude of identities is normalized and reconstructed as a dynamic, if impermanent kinship.

While Pilipp and Shull argue that films that center on AIDS effectively displace the emphasis from PWAs onto people who constitute their "family" and on the latter's negotiations of loss and caregiving, sherwood's film resists relegating the PWA to a mere object of mourning. The character of Nick acts both as glue and a force of disruption in people's lives, as his sharp wit and acerbic worldview keep his buddies on their toes. Perhaps surprisingly, there has been a marked criticism of the way the character of Nick is drawn. Writing on the film's attitude towards (homo)sexuality, Thomas Waugh asserts that "sexuality seems to be less transformational in both its personal and dramatic operation than a dramatic pretext and a psychic plateau to be left behind" (127), but seems to agree with the implication that a certain desexualization of Nick is what opens up the space for an intimacy and a kinship with Michael alternative to that of Michael and Robert. Robert Eberwein is harsher in his article on disease and masculinity, where he describes Nick's countenance as "weakness and wraithlike gauntness" (159) and encapsulates the character's narrative role by captioning a film still of Buscemi with the sentence, "The homosexual lead character in Parting Glances, who has AIDS, has no sexual partner and is seen to waste away" (158). However, the lack of sexual partner in itself, aside from suggesting Nick's trauma of sex for fear of transmission (a fear that he verbalizes in the film), does not necessarily exclude the PWA from the mechanics of kinship, conjugality or intimacy. In fact, Parting Glances presents an image of a PWA who is simultaneously full of agency and resistant to victimhood.

Throughout the film, Nick is portrayed as a character that shakes his circle of friends from their complacencies, whether they be the banality of mainstream gay culture obsessed with body image or the pretentiousness of the queer art scene (both, it should be noted, frames of thought that impede people in connecting and forging relationships due to their exclusionary nature). For example, sherwood inserts a recurring dream sequence where Nick and Michael interrupt their bourgeois friend's Greek-themed pool party and lampoon him and the beefcake models he keeps around his Fire Island property by pushing them into the pool and starting a food fight, echoing a similar scene in Miloš Forman's 1979 film Hair (a film similarly engaged with the idea of "family" in the face of death, albeit death from going to war). Similarly, he incorporates a jarring sequence where a foreign artist fetishizes Nick's condition and calls him "pregnant with death," and Nick in turn holds a knife to his throat, literalizing the closeness to death to the offender in an act of resistance to metaphorical representation. This scene, in its own way, presages director Gregg Araki's rebellious attitude to the pandemic, particularly in his film The Living End (1992), where victimhood is replaced by violent outbursts against the world. Mainly, however, it is Nick's egalitarian and parrhesiastic relationship with Michael that prevents him 
from becoming objectified as a walking image of death. The two maintain a productive verbal tension that works in both directions and prevents the PWA from being objectified, as he ostensibly would be within a more traditional format of confessional discourse. In other words, Michael remains in a discursive engagement with his friend, refusing to talk about Nick's death and resisting the deathbed confessional. Instead, they engage in parrhesia as described by Foucault-"the verbal act by which the subject... places himself in a relation of dependence with regard to the other person and at the same time modifies the relationship he has with himself" (Foucault, qtd. in Roach 25). This relationship echoes director Arthur J. Bressan Jr.'s 1985 film Buddies, the earliest AIDS film and one that repeatedly positions the buddy system as a mode of relating that is challenging and transformational for both the PWA and the caregiver.

Even from his metaphorical deathbed, Nick still has the agency and influence to simultaneously challenge his friend and remain a constructive force. While Eberwein refers to a scene where Nick unsuccessfully videotapes his will as a "mark of his [masculine] impotency" (160), the film demonstrates a particular kind of control and agency by having Nick reflect on the responsibilities in his sex life in light of his medical status and about his absent father within a singular scene. Here, he simultaneously casts off both the presumption of the "victim continuum," or the "intentional pursuit of 'deviant' and 'immoral' behaviors" typical of AIDS narratives (Hart 39), and a queer person's obligation to biological family, which in itself represents a continuation of the link between family and mortality. In so doing, Nick is drawn as an undoubtedly sexual, ethical and potent gay man with AIDS who willingly replaces his disappointing biological family with the one he has chosen for himself.

The will itself reflects Nick's allegiance to his "family," and particularly Michael, as well as the centrality of this mode of relationality in the context of AIDS. While he does leave his father ten thousand dollars that "should buy [him] a nice weekend in Atlantic City," Nick's decision to leave Michael fifty thousand, with the rest going to other friends and the Gay Men's Health Crisis "for care for poor people with AIDS and not to medical research, because if the feds can spend a trillion bucks on bombs, then they can spend a little on research" (Parting Glances), points to a reorganization of priorities when it comes to relationships. In this light, the scene where Nick tapes his will (and which Eberwein sees as the moment indicative of both the character's progressive deterioration and failing masculinity), becomes a reaffirmation of Nick's place in his milieu, as he shows his allegiance is first and foremost to his buddy, Michael, and his "family" (both the people he knows and the larger, imagined homosexual community), in contrast to his own biological father, to whom he can only wish a merry gambling trip. With this pivotal scene, Nick's roles as someone who needs help and someone who provides it, financially and otherwise, are blurred, and his masculinity is only impeded if one is to hold the traditional standards of masculinity to apply in a film that clearly rejects them and in their place values relationships that are transient (the transience is nowhere better demonstrated than in the will-recording scene, itself a staging of finitude and mortality), but also rooted in a sense of community.

Nick's mention of Gay Men's Health Crisis, or the GMHC, is not only a thinly veiled call for action and advocacy in a 1985 film that deals with the subject of AIDS. The reference, coupled with Nick's quip about the government's refusal to invest in AIDS research, is also a moment which imbues the PWA with political and personal agency, his passion for video editing echoing the video art initiatives of 1980s queer 
activists. Michael reiterates this call for action in the film's emotionally charged final movement, when he accuses Robert of leaving to escape Michael's anguish when Nick dies, proclaiming in addition that he will "go after every politician, idiot doctor and smug, born-again asshole" (Parting Glances). The political consciousness of the film remains rooted in Nick's situation, but he crucially is never understood as a martyr or victim. The film's premise of people searching for an escape from the ties that bind them is resolved not only with Robert returning to Michael and, presumably, rekindling their relationship, but also by Nick remaining at the center of his "family" and acting as both a disruptor and connecting tissue for his family of choice.

\section{Conclusion}

Eberwein writes that, "to follow the trajectory of an AIDS victim photographically is, typically, to watch the inevitable disintegration and observe the progress of death" (160). Such an outlook is easily observable in films like The Normal Heart, for example, which climaxes in Ned's boyfriend's death just after they have exchanged vows on his deathbed, or even Jonathan Larson's Rent, where the calculatedly named character Angel dies in the beginning of the second act but is omnipresent throughout, as her friends memorialize and refer to her in almost mythical terms that ultimately remove any semblance of character and instead relegate her to a metaphor. Angels in America, on the other hand, makes this canonization of the AIDS sufferer the play's main problem, with the character of Prior ultimately refusing to become a prophet and turning away from heaven's door in order to live on, in spite of the agony of his condition, "past hope" (Angels in America). That Sherwood refuses to have Nick die at the end of Parting Glances is an empowering strategy, echoing writer Andrew Holleran, whose character proclaimed that, "Everything that's happened the last twenty years, the acceptance of gays, is a, superficial, and b, because we are dying. As we should be, in their logic" (Holleran, "The Housesitter," qtd. in Pearl 156). By keeping Nick alive, Sherwood allows his central character to fly in the face of "their logic," as Holleran puts it; "they" being "every politician, idiot doctor and smug, bornagain asshole," to borrow Michael's rhetoric, as well as the society at large as a systemic web of oppression and exclusion. It is the fluid nature of the "family" that Nick is at the center of which allows an alternative to victimhood and canonization. In the face of deathbeds, finitude and mourning, the "family" of his own making is created and sustained on the notion of the PWA's own influence and agency.

\section{BIBLIOGRAPHY}

Eberwein, Robert. "Disease, Masculinity, \& Sexuality in Recent Films." Journal of Popular Film and Television 22.4 (1995): 154-161. Taylor \& Francis Online. Web. 07 May 2015.

Hart, Kylo-Patrick R. The AIDS Movie: Representing a Pandemic in Film and Television. New York: Haworth, 2000. Print. 
Hayward, Susan. Cinema Studies: The Key Concepts. London and New York: Routledge, 2002. Print. Kramer, Larry. The Normal Heart. New York, NY: New American Library, 1985. Print. Kushner, Tony. Angels in America: A Gay Fantasia on National Themes. New York: Theatre Communications Group, [1992] 2003. Print.

Laing, R. D. “The Family and the "Family.” The Politics of the Family and Other Essays. London: Tavistock Publications, 1971. 3-19. Print.

Larson, Jonathan. Rent: The Complete Book and Lyrics of the Broadway Musical. New York, NY: Applause Theatre and Cinema, [1996] 2008. Print.

Nair, Yasmin. “Against Equality, Against Marriage: An Introduction.” Against Equality: Queer Revolution, Not Mere Inclusion. Ed. Ryan Conrad. Oakland: AK, 2014. 15-21. Print.

Pearl, Monica B. AIDS Literature and Gay Identity: The Literature of Loss. New York: Routledge, 2013. Print.

Pilipp, Frank, and Charles Shull. "American Values and Images: TV Movies of the First Decade of AIDS." Journal of Popular Film and Television 21.1 (1993): 19-26. Taylor \& Francis Online. Web. 07 May 2015.

Roach, Tom. Friendship as a Way of Life: Foucault, AIDS, and the Politics of Shared Estrangement. Albany: State U of New York, 2012. Print.

Scanlan, Tom. Family, Drama, and American Dreams. Westport, CT: Greenwood, 1978. Print.

Stacey, Judith. “Gay and Lesbian Families: Queer Like Us.” All Our Families: New Policies for a New Century. Ed. Mary Ann. Mason, Arlene S. Skolnick, and Stephen D. Sugarman. Oxford: Oxford UP, 2003. 144-169. Print.

Stepić, Nikola. "Kinship as a Strategy for Living: Screening the Queer 'Family."' Concordia University, 2015. Web.

Warner, Michael. The Trouble with Normal: Sex, Politics, and the Ethics of Queer Life. Cambridge, MA: Harvard UP, 2000. Print.

Waugh, Thomas. "Erotic Self-Images in the Gay Male AIDS Melodrama." Fluid Exchanges: Artists and Critics in the AIDS Crisis. Ed. James Miller. Toronto: U of Toronto, 1992. 122-134. Print.

Filmography

Angels in America. Dir. Mike Nichols. USA, Italy, 2003. 352 min. HBO. DVD.

Buddies. Dir. Arthur J. Bressan Jr. USA, 1985. 81 min. New Line Cinema. DVD.

Desperate Housewives. USA, 2004-2012. ABC. Television.

Early Frost, An. Dir. John Erman. USA. 1985. 95 min. Wolfe Video. DVD.

Hair. Dir. Miloš Forman. USA, 1979. 121 min. United Artists. DVD.

Living End, The. Dir. Gregg Araki. USA, 1992. 92 min. Cineplex Odeon Films. DVD.

Longtime Companion. Dir. Norman René. USA, 1989. 96 min. Samuel Goldwyn

Company. DVD.

Modern Family. USA, 2009-Present. ABC. Television.

New Normal, The. USA, 2012-2013. NBC. Television.

Normal Heart, The. Dir. Ryan Murphy. USA, 2014. 132 min. HBO. DVD. 
Parting Glances. Dir. Bill Sherwood. USA, 1986. 90 min. Cinecom. DVD.

Philadelphia. Dir. Jonathan Demme. USA, 1993. 125 min. TriStar Pictures. DVD.

Rent. Dir. Christopher Columbus. USA, 2005. 135 min. Columbia Pictures. DVD.

\section{NOTES}

1. In the thesis titled Kinship as a Strategy for Living: Screening the Queer "Family," submitted in fulfillment of the requirements for the MA in Film Studies from Concordia University in Montreal, Canada, a chapter of which this paper is derived from, I also look at The Boys in the Band (William Friedkin, 1970) and Paris Is Burning (Jennie Livingston, 1990) as examples where the queer "family" is formulated vis-à-vis family drama and soap operas, respectively.

\section{ABSTRACTS}

As a counterpoint to the emerging homonormativity of the twenty-first century, this paper seeks to identify and reevaluate the potential of queer chosen families as they are cinematically mediated, and historically located, in the context of the AIDS epidemic. With Bill sherwood's 1986 film Parting Glances as a case study, the paper argues that the melodramatic mode of these films, with the repetition of tropes such as caregiving, mourning and funerals, ushers an alternative mode of familiality into queer narratives and champions the queer chosen family. In this sense, it is argued that to look at the evolution of queer familial life means to look at a long process of transference of one social modality to another, and the AIDS film specifically as a place where familial relationality is emulated and transformed through relations based in love, friendship and parrhesia.

\section{INDEX}

Keywords: AIDS, Bill Sherwood, buddy system, caregiving, chosen family, death, family, melodrama, New York City, parrhesia, Parting Glances, queer kinship, transference

\section{AUTHOR}

\section{NIKOLA STEPIĆ}

Concordia University 